\title{
Gene expression profiling: identification of genes with altered expression in Ayu 17-449 knockout mice
}

\author{
Y. Li ${ }^{1 *}$, T.T. Huang ${ }^{2 *}$, H. Tang ${ }^{2}$, K.I. Yamamura ${ }^{3}$ and X.Y. Pu ${ }^{1}$ \\ ${ }^{1}$ Department of Clinical Laboratory, Xinqiao Hospital, \\ Third Military Medical University, Chongqing, China \\ ${ }^{2}$ Key Laboratory of Molecular Biology on Infectious Diseases, \\ Ministry of Education, Chongqing Medical University, Chongqing, China \\ ${ }^{3}$ Department of Developmental Genetics, \\ Institute of Molecular Embryology and Genetics, Kumamoto University, \\ Kumamoto, Japan \\ *These authors contributed equally to this study. \\ Corresponding author: $\mathrm{Y}$. Li or H. Tang \\ E-mail: liyi-12qq@163.com / tanghua86162003@yahoo.com.cn
}

Genet. Mol. Res. 10 (3): 1533-1544 (2011)

Received January 8, 2011

Accepted Abril 10, 2011

Published August 1, 2011

DOI 10.4238/vol10-3gmr1158

\begin{abstract}
Ayu17-449, a novel gene in mice, has been identified as a tumor-suppressor gene in myeloid malignancy; its product catalyzes the conversion of 5-methylcytosine of DNA to 5-hydroxymethylcytosine. However, in vivo, its functional target genes and biological function have remained unclear. Based on the assumption that alterations in the expression of the Ayu17-449 gene affect the expression of other related genes, we screened a microarray of altered gene expression in Ayu17-449-/ and Ayu17-449 $9^{+/+}$mice. We
\end{abstract}


identified 4049 genes with altered expression, including 1296 upregulated (fold change $\geq 2$ ) and 2753 down-regulated (fold change $\leq 0.5$ ) genes in knockout mice compared with control mice. We then used qRT-PCR and RT-PCR to validate the chip data. Gene ontology and pathway analysis were performed on these altered genes. We found that these altered genes are functional genes in the complement and coagulation cascades, metabolism, biosynthesis, transcriptional regulation, proteolysis, and intracellular signaling pathways, such as the peroxisome proliferator-activated-receptor signaling pathway, the TNF- $\alpha-N F-\kappa B$ pathway, the Notch signaling pathway, the MAPK signaling pathway, and the insulin signaling pathway. The results of our genome-wide comprehensive study could be helpful for comprehending the underlying functional mechanisms of the Ayu17-449 gene in mammals.

Key words: Ayu17-449 knockout mice; Gene microarray; TET-2 (tet oncogene family member 2)

\section{INTRODUCTION}

Ayu17-449, a novel gene on mouse chromosome 3, was identified by the gene trapping technique previously reported by Tang et al. (2006). In NCBI database analysis, Ayu17-449 is also called TET-2 (tet oncogene family member 2). It belongs to a novel, well-conserved, protein family but with unclear biological function, the TET protein family, including three members (TET-1, TET-2 and TET-3). Current, related studies about the function of TET-2 were restricted to its identification as a tumor-suppressor gene commonly mutated in myeloid malignancies, including myelodysplastic syndromes (MDS; Langemeijer et al., 2009), chronic myelomonocytic leukemia (CML; Kosmider et al., 2009) or acute myeloid leukemia (AML; Nibourel et al., 2010), which may play critical roles in regulating the survival, growth and differentiation of myeloid cells. In addition, Ito et al. (2010) proved that TET-2 protein could catalyze the conversion of 5 -methylcytosine $(5 \mathrm{mC})$ of DNA to 5-hydroxymethylcytosine $(5 \mathrm{hmC})$ in U2OS cells. Despite this, the function of Ayu17-449 protein regulation mechanism in the cell physiological state remains unresolved, as does the question of whether Ayu17-449 protein is a key factor in controlling the conversion of normal genes to tumor genes.

Gene knockout studies in rodents confirmed the central role of Ayu17-449 in embryonic development. Tang et al. (2008) showed that in Ayu17-449 null mice, development appears largely normal until embryonic day 19 (E19), and embryos die (at P0-P1) from unidentified causes. In adult mice, Ayu17-449 showed a characteristic regional distribution in brain and kidney. Ayu17-449 was identified having the granin motif, which was important for acidic granule formation in mouse proximal convoluted tubules (Tang et al., 2008). However, detailed information on the functions of granules in the proximal tubule cell was as yet unavailable. To clarify the role of Ayu17-449 in embryonic tissue development, we used high-density oligonucleotide probe-based cDNA microarray to profile gene expression patterns of Ayu 17-449-/- mouse brains at stage E19 compared to 
age-matched control mouse brains, and identified the major clusters of up-regulated and down-regulated genes, which were subjected to detailed analysis.

\section{MATERIAL AND METHODS}

\section{Animals}

Heterozygous Ayu17-449 mice (Ayu17-449+-) were produced in the Center for Animal Resources and Development, Kumamoto University, Japan, and fed in the Center of Experimental Animals, Chongqing Medical University, China. The mice were conventionally housed in polyethylene cages at a constant temperature of $22 \pm 2{ }^{\circ} \mathrm{C}$, relative humidity of $55 \%$, and on a 12-h light/dark cycle (lights on from 8:00 to 20:00). Mice were fed a standard chow diet, and food and water were provided ad libitum. The experimental protocols were conducted in accordance with internationally accepted principles for laboratory animal use. Five heterozygous males were mated with 10 heterozygous females to produce wild-type mice, heterozygous mice, and homozygous mice. Because the homozygous mutant mice died at P0, homozygous mice were obtained by abdominal delivery on the 19th day of pregnancy. The brain tissues of all offspring mice at E19 were taken out and immediately frozen in liquid nitrogen and then kept at $-80^{\circ} \mathrm{C}$ until further analysis. Genotyping was done by polymerase chain reaction (PCR) analysis on tail genomic DNA.

\section{RNA extraction and microarray hybridization}

Brain samples from 3 wild-type $\left(\right.$ Ayu 17-449 $\left.9^{+/+}\right)$and 3 homozygous $\left(A y u 17-449^{-/-}\right)$ mice were pooled for each genotype. Each pool was placed in $3 \mathrm{~mL}$ Trizol reagent (Invitrogen Corporation, Carlsbad, CA, USA) and homogenized with a homogenizer. After extraction with chloroform, RNA was precipitated with isopropanol. The resultant pellet was finally resuspended in TE buffer (10 mM Tris- $\mathrm{HCl}, \mathrm{pH} 7.5,1 \mathrm{mM}$ EDTA). After a DNase digestion step, RNA quantification and quality assurance were assessed by optical density measurement at 260/280 nm (between 1.8 and 2.1) (Gene Quant Pro), and RNA integrity and genome DNA contamination were tested by denaturing agarose gel electrophoresis. Single-color gene-expression profiles were generated for test and control samples. These profiles were generated using customized $4 \times 44 \mathrm{~K}$ oligonucleotide microarrays produced by Agilent Technologies (Palo Alto, CA, USA). The mouse wholegenome microarrays covered more than 41,000 genes and transcripts. The representative sequences were derived from leading public databases including RefSeq, Ensembl, Unigene, UCSC Goldenpath, and others. The RNA samples were amplified and labeled using the Agilent Quick Amp labeling kit (Agilent Technologies) according to manufacturer instructions and hybridized with the Agilent mouse whole-genome oligonucleotide microarray in Agilent's SureHyb hybridization chambers. After hybridization and washing, the hybridized slides were scanned with the Agilent DNA microarray scanner (G2505B) and processed with the Agilent Feature Extraction Analytics software (version 9.5.3). The Feature Extraction placed microarray grids, rejected outlier pixels, determined feature intensities and ratios, flagged outlier pixels, and compiled QC reports. The procedure above was carried out by KangChen Bio-Tech, Shanghai, China. 


\section{Real-time quantitative PCR (qRT-PCR) or RT-PCR}

The reliability of chip results was not only confirmed by qRT-PCR analysis of the selected genes, including Ccl4, Nox3, Gtf2h2, Pgam2, Ccr10, and mouse $\beta$-actin gene as control, but also by RT-PCR analysis Alb, Serpinalb, Fga, Serpinald, these selected genes, and mouse GAPDH gene as control. Primer sequences for cDNA synthesis were designed by the ABI Primer Express software. The optimal annealing temperature for each primer set was determined prior to the analysis of experimental samples. Prior to RT performance, DNase I (Promega, USA) was used to digest the genomic DNA. An amount

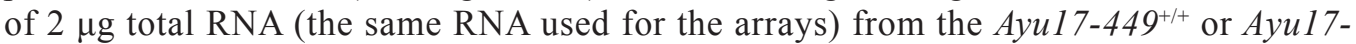
$449^{--}$mice was individually subjected to reverse-transcription with random primers and a reverse transcription kit (Promega). In real-time PCR, triplicate $25-\mu \mathrm{L}$ real-time PCRs were run, containing $12.5 \mu \mathrm{L}$ SYBR Green PCR master mix, $1 \mu \mathrm{L}$ of a primer stock solution containing $10 \mu \mathrm{M}$ of both forward and reverse primers, $1 \mu \mathrm{L}$ cDNA template, and $10.5 \mu \mathrm{L}$ nuclease-free water. The following standard PCR conditions were used: one cycle at $90^{\circ} \mathrm{C}$ for $10 \mathrm{~min}$ and 40 cycles at $94^{\circ} \mathrm{C}$ for $15 \mathrm{~s}$, the primer-specific annealing temperature for $40 \mathrm{~s}$ and $72^{\circ} \mathrm{C}$ for $60 \mathrm{~s}$. Because different primers were used, every primer has its suitable annealing temperature, e.g., $58^{\circ}, 59^{\circ}, 60^{\circ} \mathrm{C}$. Here, we described this process as primer-specific annealing temperature. A cycle threshold (CT) was assigned at the beginning of the logarithmic phase of PCR amplification, and duplicate $\mathrm{CT}$ values were analyzed by Microsoft Excel. The $2^{-\Delta \Delta \mathrm{Ct}}$ method (Livak and Schmittgen, 2001) was used to determine the relative expression of the gene in each sample. In RTPCR, triplicate PCR mixtures were run, containing $5 \mu \mathrm{L} 5 \mathrm{X}$ PrimeSTAR buffer, $2 \mu \mathrm{L}$ dNTP mixture, $2 \mu \mathrm{L}$ of each primer (Table 1), $2 \mu \mathrm{L}$ SureStart Taq polymerase (Takara), $1 \mu \mathrm{L}$ cDNA template, and $13 \mu \mathrm{L}$ nuclease-free water preparation per $25-\mu \mathrm{L}$ reaction. The following standard PCR conditions were used: one cycle at $95^{\circ} \mathrm{C}$ for $10 \mathrm{~min}$ and 40 three-step cycles $\left(20 \mathrm{~s}\right.$ at $95^{\circ} \mathrm{C}, 30 \mathrm{~s}$ at $60^{\circ} \mathrm{C}$, and $30 \mathrm{~s}$ at $\left.72^{\circ} \mathrm{C}\right)$, and a final incubation at $72^{\circ} \mathrm{C}$ for $5 \mathrm{~min}$. PCR products were then detected by $1.0 \%$ agarose gel electrophoresis.

\begin{tabular}{|c|c|c|c|}
\hline Gene & Product length & Forward primer & Reverse primer \\
\hline \multicolumn{4}{|l|}{ A } \\
\hline $\mathrm{Ccl} 4$ & $56 \mathrm{bp}$ & CCCGAGCAACACCATGAAG & CCACGAGCAAGAGGAGAGAGA \\
\hline Nox3 & $56 \mathrm{bp}$ & TCTCCGGCTGCACAATGTC & CTGCCTGCCATTCAGCATAG \\
\hline Gtf $2 h 2$ & $60 \mathrm{bp}$ & GTGGCCCGAAGCGAGTT & TTTACTGTCCCCCGTGTTCAG \\
\hline Pgam 2 & $56 \mathrm{bp}$ & GAGGTTCCTGGGAGACGAAGA & GGGCAGCAACAGCTTCCAT \\
\hline Corlo & $60 \mathrm{bp}$ & ССТCTACTCGGCCTCTTTCCA & CGGTCGGCGCTGATACAG \\
\hline$m \beta$-actin & $59 \mathrm{bp}$ & cga tgc cct gag get ctt $t$ & tgg atg cca cag gat tcc at \\
\hline \multicolumn{4}{|r|}{ 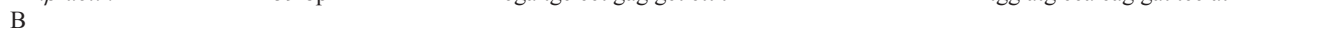 } \\
\hline$A l b$ & $857 \mathrm{bp}$ & TTGCATGAAGTTGCCAGAAG & ACGAGAGTTGGGGTTGACAC \\
\hline Serpinalb & $501 \mathrm{bp}$ & GGTCTACTGCTTCTGGCAGG & СACTTTCTTGGCCTCCTCTG \\
\hline Fga & $994 \mathrm{bp}$ & CTGGCTCAGACTCTGGGAAC & TTTAAGGTTAGGGGGTTGGG \\
\hline Serpinald & $347 \mathrm{bp}$ & AAACATCGGAGGCTGACATC & CTCAGGATCGAATGGCTGTT \\
\hline $\operatorname{Pgam} 2$ & $590 \mathrm{bp}$ & GCTGCCACCTAGAGTTCCTG & GGGCTGCAATAAGCACTCTC \\
\hline Cer 10 & $371 \mathrm{bp}$ & AACCCAGTGTCTCCCTGATG & CAGCCACACGAAGACTGAAA \\
\hline$m G A P D H$ & $391 \mathrm{bp}$ & gga aag ctg tgg cgt gat $g$ & ctg ttg ctg tag ccg tat tc \\
\hline
\end{tabular}

\section{Microarray data analysis}

The Agilent GeneSpring GX software (version 7.3 or later) was used to calculate and 
record the signal intensities representing the gene expression levels generated by the Agilent $4 \times 44 \mathrm{~K}$ One-Color Whole Genome Microarray. For inter-array normalization, a median normalization was applied. For data analysis, fold changes were applied to select the differentially expressed genes using 2-fold change cutoff. Genes with 2-fold higher expression compared to control were regarded as up-regulated gene; genes with 2-fold lower expression were regarded as down-regulated genes, and 0.50- to 1.99-fold changes were regarded as nonsignificant. Therefore, the profiling identified a subset of the total number of differentially expressed genes. Gene ontology (GO) analysis and pathway analysis were then performed on these subsets of genes.

\section{RESULTS}

\section{Profiling of differential gene expression in Ayu17-449-/- mice}

To elucidate the mechanism of growth regulation by Ayu17-449, we used an Ayu17449 knockout mouse model described previously (Tang et al., 2008). Loss of Ayu17-449 function in the mouse results in death around day P0 (the day of birth), but dose not appear to affect early development processes such as body axis formation (Tang et al., 2008). At embryonic stage E19, these brain tissues were taken out and microarray analysis was done for determining the distinction of gene expression between Ayu 17-449-- and Ayu17-449 ${ }^{+/+}$mice. Comparison analysis revealed 1296 up-regulated genes and 2753 down-regulated genes in Ayu 17-449-mice. The expression of Ccl4, Homer1, Gtf2h2, Tubb2a, Xist, Slc22a17, Fxyd6, Snrpn, Ly6h, Adrm1, Arf5, Snurf, 2010107G23Rik, BC005764, Mgat4b, 2210016L21Rik, Tuba1b, Cct2, Podxl2, Ogfr, and Strn4 was markedly increased (Table 2), and that of Pzp, Apoal, Serpinc1, Uox, Igfbp1, Serpinale, Fgg, Ahsg, Ambp, Hp, Cpb2, Fgb, F2, Serpinald, Kng1, Serpinalb, Apoh, Fga, Fabpl, and Alb1 was dramatically repressed (Table 3).

\begin{tabular}{llll}
\multicolumn{1}{l}{ Table 2. Highly up-regulated genes in Ayul7-449-- mice in comparison with wild-type mice. } \\
\hline GenBank & Gene symbol & Fold change & Description \\
\hline NM_013652 & Ccl4 & 411.2 & Chemokine (C-C motif) ligand 4 \\
NM_011982 & Homerl & 41.45 & Homer homolog 1 (Drosophila) \\
BC016231 & Gtf2h2 & 25.5 & General transcription factor II H, polypeptide 2 \\
NM_009450 & Tubb2a & 18.95 & Tubulin, beta 2a \\
L04961 & Xist & 15.4 & Inactive X-specific transcripts \\
NM_021551 & Slc22a17 & 14.44 & Solute carrier family 22 (organic cation transporter), member 17 \\
NM_022004 & Fxyd6 & 14.1 & FXYD domain-containing ion transport regulator 6 \\
NM_013670 & Snrpn & 14 & Small nuclear ribonucleoprotein N \\
NM_011837 & Ly6h & 13.61 & Lymphocyte antigen 6 complex, locus H \\
NM_019822 & Adrm1 & 13.47 & Adhesion regulating molecule 1 \\
NM_007480 & Arf5 & 13.47 & ADP-ribosylation factor 5 \\
NM_033174 & Snurf & 11.92 & SNRPN upstream reading frame \\
NM_027251 & 2010107G23Rik & 11.78 & RIKEN cDNA 2010107G23 gene \\
NM_181681 & BC005764 & 11.63 & cDNA sequence BC005764 \\
NM_145926 & Mgat4b & 11.59 & Mannoside acetylglucosaminyltransferase 4, isoenzyme B \\
NM_028211 & 2210016L21Rik & 11.31 & RIKEN cDNA 2210016L21 gene \\
NM_011654 & Tubalb & 10.9 & Tubulin, alpha 1B \\
NM_007636 & Cct2 & 10.75 & Chaperonin subunit 2 (beta) \\
NM_176973 & Podxl2 & 10.41 & Podocalyxin-like 2 \\
NM_031373 & Ogfr & 10.26 & Opioid growth factor receptor \\
NM_133789 & Strn4 & 10.25 & Striatin, calmodulin binding protein 4 \\
\hline
\end{tabular}




\begin{tabular}{|c|c|c|c|}
\hline GenBank & Gene symbol & Fold change & Description \\
\hline NM 007376 & Pzp & 0.000972 & Pregnancy zone protein \\
\hline NM_009692 & Apoal & 0.000816 & Apolipoprotein A-I \\
\hline NM_080844 & Serpincl & 0.000812 & Serine (or cysteine) peptidase inhibitor, clade C (antithrombin), member 1 \\
\hline NM 009474 & Uox & 0.000807 & Urate oxidase \\
\hline NM_008341 & $\lg f b p l$ & 0.000785 & Insulin-like growth factor binding protein 1 \\
\hline NM_009247 & Serpinale & 0.000757 & Serine (or cysteine) peptidase inhibitor, clade A, member 1e \\
\hline NM 133862 & Fgg & 0.000739 & Fibrinogen, gamma polypeptide \\
\hline NM 013465 & Ahsg & 0.000731 & Alpha-2-HS-glycoprotein \\
\hline NM 007443 & $A m b p$ & 0.000667 & Alpha 1 microglobulin/bikunin \\
\hline NM_017370 & $H p$ & 0.000618 & Haptoglobin \\
\hline $\mathrm{AF} 186188$ & $C p b 2$ & 0.000613 & Carboxypeptidase B2 (plasma) \\
\hline NM 181849 & $F g b$ & 0.000608 & Fibrinogen, B beta polypeptide \\
\hline NM 010168 & $F 2$ & 0.00054 & Coagulation factor II \\
\hline NM 009246 & Serpinald & 0.000502 & Serine (or cysteine) peptidase inhibitor, clade A, member $1 \mathrm{~d}$ \\
\hline NM 023125 & Kngl & 0.000486 & Kininogen 1 \\
\hline NM_009244 & Serpinalb & 0.000478 & Serine (or cysteine) peptidase inhibitor, clade A, member $1 \mathrm{~b}$ \\
\hline NM_013475 & Apoh & 0.00045 & Apolipoprotein $\mathrm{H}$ \\
\hline NM 010196 & $F g a$ & 0.000445 & Fibrinogen, alpha polypeptide \\
\hline NM_017399 & Fabpl & 0.000332 & Fatty acid binding protein 1 , liver \\
\hline NM 009654 & Albl & 0.000271 & Albumin 1 \\
\hline
\end{tabular}

\section{Validation of microarray results by qRT-PCR or RT-PCR}

To confirm the chip results, five up-regulated genes were chosen for qRT-PCR performance. The results showed that Ccl4, Nox3, Gtf $2 \mathrm{~h} 2$, and Pgam 2 expression patterns were similar to that observed in the microarray experiments, among which Pgam 2 mRNA expression showed no statistical significance difference between wide-type and Ayu17-449-deficient mice by qRT-PCR (Figure 1), but Ccr10 was not confirmed as an up-regulated gene in Ayu17$449^{-/}$mice by qRT-PCR or RT-PCR (data not shown), which was in opposition with microarray data (Figure 1). Meanwhile, four significantly down-regulated genes including Alb1, Serpinalb, Fga, and Serpinald were identified by RT-PCR. These results were correlated with microarray data (Figure 2).

\section{Bioinformatic analysis}

Profiling identified a subset of the total number of probes analyzed by Agilent wholegenome oligo microarray that show differential expression. The identified differential genes were annotated in the GO format for biological function classification and in the pathway analysis format for elucidation of whole chains of events in brain tissues of Ayu 17-449-/- compared with $A y u 17-449^{+/+}$mice. In the GO, the identified genes including the intracellular membranebound organelle $(\mathrm{P}=7.37 E-16)$, membrane-bound organelle $(\mathrm{P}=7.37 E-16)$, mitochondrion $(\mathrm{P}$ $=3.27 E-11)$, cytoplasm $(\mathrm{P}=1.83 E-10)$, and ribonucleoprotein complex $(\mathrm{P}=7.52 E-05)$ were overrepresented (Figure 3). Pathway analysis revealed that, in Ayu17-449-/- mice, many pathway genes had disordered expression, especially in complement and coagulation cascades $(\mathrm{P}$ $=4.70 E-14)$, glycine, serine and threonine metabolism $(\mathrm{P}=1.02 E-07)$, amino acid metabolism $(\mathrm{P}=2.43 E-07)$, mRNA processing $(\mathrm{P}=8.27 E-07)$, purine metabolism $(\mathrm{P}=2.42 E-05)$, drug metabolism-cytochrome $\mathrm{P} 450(\mathrm{P}=7.61 E-05)$, and heme biosynthesis $(\mathrm{P}=8.69 E-05)$, and so on (Table 4). 

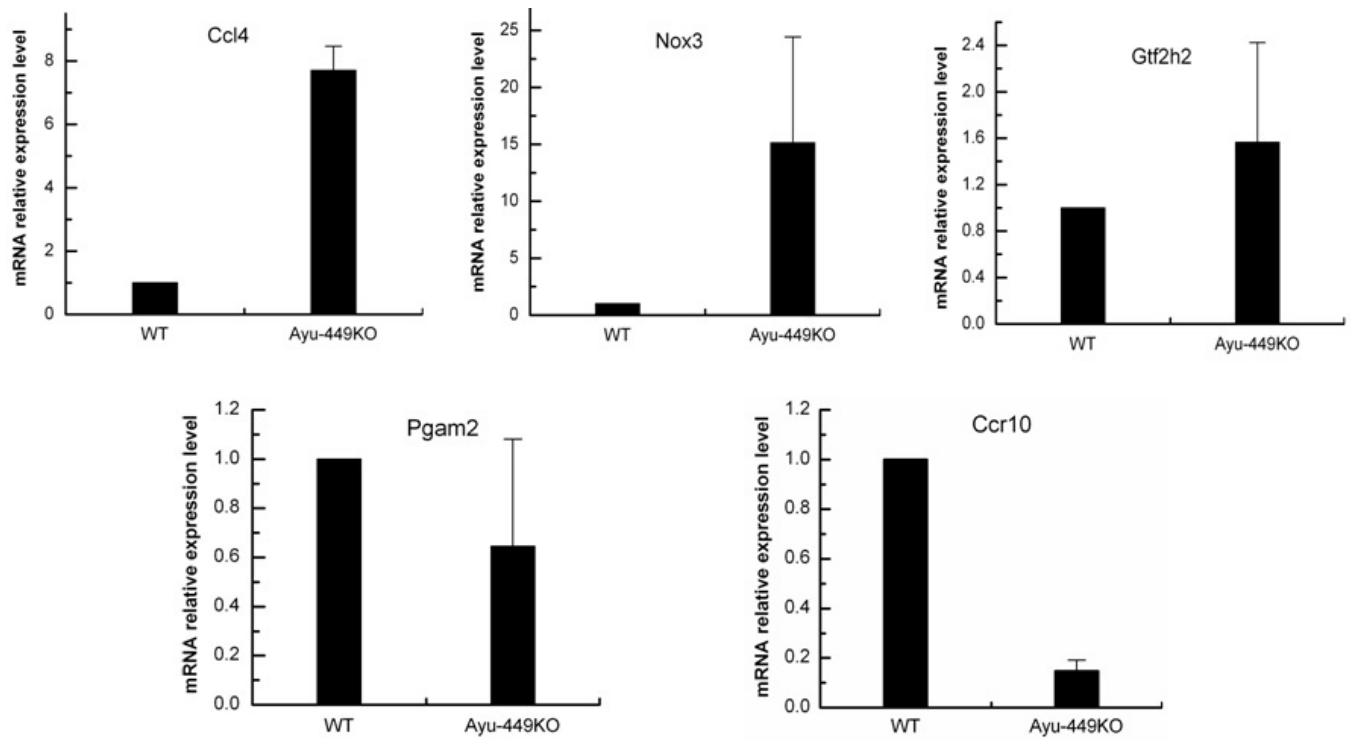

Figure 1. Validation of microarray results by real-time PCR. The results represent quantification of mRNA levels relative to $\beta$-actin. Normalized expression values obtained by real-time PCR $(\mathrm{N}=3)$. WT $=$ wild type.

\section{Ayu-449 KO WT}

Alb1

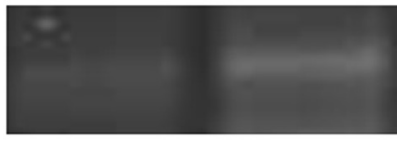

Serpinalb

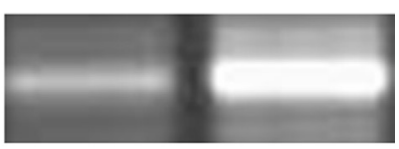

Fga

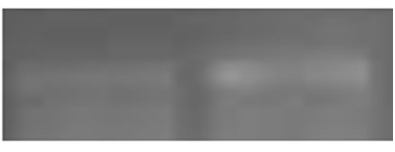

\section{Serpinald}

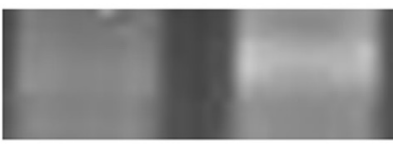

\section{mGAPDH}

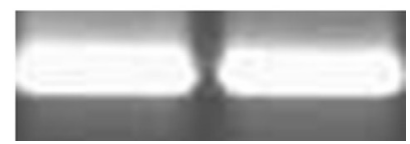

Figure 2. mRNA expression levels of altered genes in microarray validated by RT-PCR. Results show that Alb, Serpinalb, Fga, and Serpinald were down-regulated genes, using mouse GAPDH gene as an internal standard; all of which were consistent with chip data. WT = wild type. 


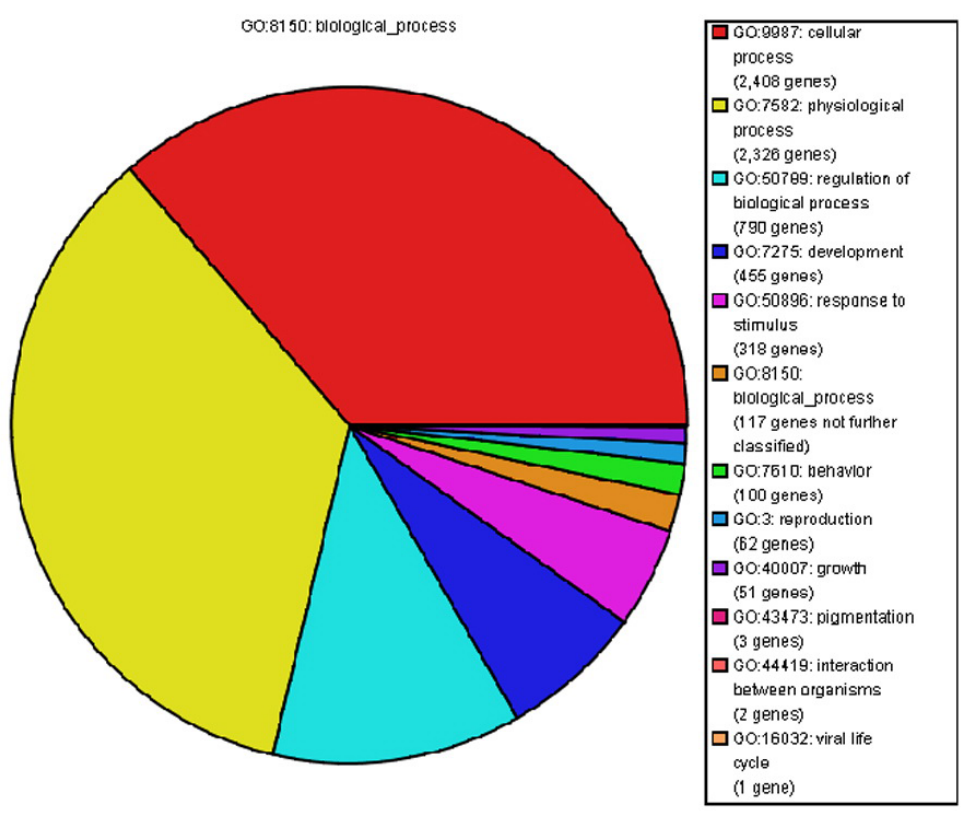

Figure 3. Gene ontology (GO) analysis used for analysis of the altered genes. Differentially expressed transcripts mapped to numerous biological processes of the hierarchical GO system. The meaning of each color representative is listed on the right side of the legend.

Table 4. Altered mRNA expression patterns of wild-type and homozygous Ayu17-449 knockout mice over the investigated period of time (E19) as analyzed by the Pathway Analysis software.

\begin{tabular}{|c|c|c|}
\hline Pathway & $\begin{array}{c}\text { Number of common genes } \\
\text { with each pathway }\end{array}$ & P value \\
\hline KEGG PATHWAY: Complement and coagulation cascades - Mus musculus (mouse) & 44 & $4.70 \mathrm{E}-14$ \\
\hline KEGG PATHWAY: Glycine, serine and threonine metabolism - Mus musculus (mouse) & 24 & $1.02 \mathrm{E}-07$ \\
\hline Amino acid metabolism & 38 & $2.43 \mathrm{E}-07$ \\
\hline mRNA processing (Mus musculus) & 140 & 8.27E-07 \\
\hline KEGG PATHWAY: Purine metabolism - Mus musculus (mouse) & 49 & $2.42 \mathrm{E}-05$ \\
\hline KEGG PATHWAY: Drug metabolism - cytochrome P450 - Mus musculus (mouse) & 24 & $7.61 \mathrm{E}-05$ \\
\hline Heme biosynthesis & 7 & $8.69 \mathrm{E}-05$ \\
\hline Statin pathway (PharmGKB) & 11 & 0.000144 \\
\hline KEGG PATHWAY: PPAR signaling pathway - Mus musculus (mouse) & 25 & 0.000147 \\
\hline Circadian exercise & 22 & 0.00017 \\
\hline Fatty acid biosynthesis & 12 & 0.000314 \\
\hline KEGG PATHWAY: Pyrimidine metabolism - Mus musculus (mouse) & 30 & 0.000353 \\
\hline Blood clotting cascade & 10 & 0.000384 \\
\hline TNF-alphaNF- $\kappa$ B signaling pathway & 54 & 0.000399 \\
\hline Translation factors & 22 & 0.000711 \\
\hline KEGG PATHWAY: Ribosome - Mus musculus (mouse) & 28 & 0.000806 \\
\hline Cytoplasmic ribosomal proteins & 27 & 0.000834 \\
\hline KEGG PATHWAY: Styrene degradation - Mus musculus (mouse) & 3 & 0.000941 \\
\hline
\end{tabular}

\section{DISCUSSION}

The use of gene knockout mice to study the biological function of a certain gene has 
attracted much attention among many researchers (Callow et al., 2000; Monti et al., 2001; Choi et al., 2007). In our experiments, to elucidate the biological function of the novel gene Ayu17-449, we produced the Ayu17-449 knockout mouse by gene trap technology (Tang et al., 2008). The finding that each Ayu 17-449-/ mouse died on P0 caught our attention. In other words, once some sustaining conditions from the mother ended, some physiological defects related to Ayu17-449 gene would have a direct lethal effect on fetal mice. We used brain tissues from E19 Ayu17-449-- or Ayu17-449 ${ }^{+/+}$mice to compare differential gene expression between them by analysis of the mouse whole-genome microarray data. We found 1296 genes (fold change $\geq 2$ ) that were up-regulated and 2753 genes (fold change $\leq 0.5$ ) down-regulated in Ayu17-449- mice. Using GO and pathway analyses, we then studied Ayu17-449 gene function by means of exploring the physiological changes caused by Ayu17-449-regulated genes.

The microarray assay showed that chemokine (C-C motif) ligand 4 ( Ccl4) was a strong up-regulated gene (fold change $=411.2)($ Table 2$)$ in Ayu17-449-- mice, which should be suppressed by Ayu17-449 protein in normal physiological status. As reported in a previous study, $\mathrm{Ccl} 4$ acts as a critical factor in mediating inflammatory processes, promoting beneficial leukocyte recruitment to infected tissues and the clearance of the microbes (Khuu et al., 2007). However, Bless et al. (2000) demonstrated that Ccl4 also contributed to host tissue damage associated with some inflammatory diseases. Therefore, Ayu 17-449 deficiency probably enhanced immunological damage caused by $\mathrm{Ccl} 4$ overexpression. This would be an important cause of death in Ayu17-449-- mice.

Our research revealed that Ayu17-449 may play key roles in hematopoiesis and regulate production of some blood coagulation factors. The chip results showed that three fibrinogen genes ( $F g a, F g b, F g g)$ were extremely down-regulated. Their fold changes were $0.000445,0.000608$ and 0.000739 , respectively. Fibrinogen, which is a symmetry dimer composed of three pairs of polypeptide chains termed $\alpha$ (or A), $\beta$ (or B) and $\gamma$, is the main clot structural precursor protein and displays its function when it is enzyme-cleaved into fibrin by thrombase (Doolittle, 2003). Fibrin is an essential molecule that mediates platelet adhesion and aggregation, which are vital for the coagulation cascade (Ruggeri, 1997). In addition, our results showed that the serine (or cysteine) peptidase inhibitor, clade C (antithrombin), member 1 (Serpinc1) is 0.000812-fold down-regulated. Antithrombin is one of the most important serine protease inhibitors of blood coagulation; it inactivates thrombin and several serine proteases, including blood coagulation factors IXa, Xa, XIa, XIIa (Blajchman et al., 1992). All antithrombin-null mice could not survive at the 16.5 gestational days (Ishiguro et al., 2000). Serine (or cysteine) peptidase inhibitor, clade F, member 2 (Serpinf2) was also substantially down-regulated (0.0048-fold) in Ayu 17-449- mice. Serpinf2 is the principal inhibitor of plasmin and inhibits fibrinolysis and another serine (or cysteine) peptidase inhibitor with coagulation function (Aoki, 2005). Interestingly, our results revealed that factor $\mathrm{X}(F X)$, which is a major structural component of the blood clot, was also down-regulated about 0.00274fold. $F X$ can convert prothrombin to thrombin and promotes thrombus formation by activating platelets and converting fibrinogen to fibrin (Aasrum and Prydz, 2002). Moreover, some groups have proven that $F X$ deficiency in mice causes partial embryonic lethality or death at birth from fatal neonatal bleeding or perinatal lethality (Dewerchin et al., 2000). Further studies are needed to determine the concrete roles that the Ayu17-449 gene plays in precoagulation or anticoagulation.

Our results suggest that $A y u 17-449$ gene could influence fetal liver function of lipid 
metabolism. Alpha-2-HS-glycoprotein (Ahsg), fatty acid binding protein 1 (Fabpl), alpha2-glycoprotein 1, zinc (Azgp1), angiopoietin-like 3 (Angptl3), hydroxysteroid (17-beta) dehydrogenase 2 (Hsd17b2), and carboxypeptidase N polypeptide 1 (Cpnl) are genes that show significant down-regulation in Ayu17-449-- mice. Ahsg (fetuin) (fold change $=0.000731$ ) is a member of the cystatin superfamily of cysteine protease inhibitors, which is an abundant serum protein in adult mammals and is expressed in many organs during embryogenesis (Terkelsen et al., 1998). Ahsg could act as a molecular carrier for the transportation of some insoluble molecules. It plays a significant role in promoting weight gain and insulin resistance, and may be a novel therapeutic target for type 2 diabetes mellitus, obesity or other insulinresistant diseases (Mathews et al., 2002). Ahsg-null mice display the properties of high insulin sensitivity and obesity resistance (Mathews et al., 2006). Furthermore, Ahsg prevents extraosseous calcification induced by uremia and phosphate challenge (Westenfeld et al., 2007). Intracellular fatty acid binding proteins $(F A B P S), 0.000332$-fold down-regulation compared to Ayu $17-449^{+/+}$mice, are small, soluble and abundant cytoplasmic proteins. FABPs can also bind fatty acids and other small hydrophobic molecules. Although they have broad substrate specificity, they are commonly expressed in mammalian enterocytes and hepatocytes. Intracellular FABPs are considered to some degree to be involved in the process of cellular uptake, intracellular transport and esterification of long-chain fatty acids and storage and metabolism of their respective ligands, and possibly in other cellular processes, such as differentiation or regulation of gene expression (McArthur et al., 1999). Recently, loss of intestinal fatty acid binding protein was shown to increase the susceptibility of high fat diet-induced fatty liver in male mice, and it has been confirmed that FABP gene alteration promotes age-dependent obesity in female mice (Agellon et al., 2007; Martin et al., 2008). Azgp, which was down-regulated 0.00894-fold in Ayu17-449-- mice, is a possible candidate gene for controlling weight, elucidation of polygenic inheritance, and age-dependent changes in the genetic control of obesity (Gohda et al., 2003). Angiopoietin-like protein 3 (Angptl3), a member of the vascular endothelial growth factor family of proteins, inhibits lipoprotein metabolism through its capacity to inhibit lipoprotein lipase (LPL) (Ge et al., 2004). LPL is known to play a central role in overall lipid metabolism and is associated with several pathophysiological conditions, such as atherosclerosis, obesity, and diabetes (Mead and Ramji, 2002). Moreover, Angptl3 acts as an inhibitor of endothelial lipase and may be involved in the regulation of plasma highdensity lipoprotein (HDL) cholesterol and HDL phospholipid levels in humans and rodents (Shimamura et al., 2007). Hydroxysteroid (17- $\beta$ ) dehydrogenase 2 (HSD17B2), another downregulated gene (0.058472-fold) in Ayu 17-449-^ mice, is vital for lipid metabolism. HSD17B2 is a member of the aldo-keto reductase superfamily and catalyzes the conversion between 17-keto and 17 $\beta$-hydroxysteroids. In addition, some HSD17B enzymes have been shown to be involved in other metabolic pathways, such as $\beta$-oxidation of fatty acids and oxidation of branched- and straight-chain fatty acids (Baes et al., 2000).

Knockout Ayu17-449 gene would decrease the expression of key signal transduction pathway-related genes, for instance, HSD17B2 (fold change $=0.00881)$, angiotensinogen (fold change $=0.31)$, Mn superoxide dismutase $(\operatorname{Sod} 2)$ (fold change $=0.358)$, SMAD family member $5($ Smad5) $($ fold change $=0.392)$, potassium inwardly-rectifying channel, subfamily J, member $8(K C N J 8)$ (fold change $=0.397), 3$ beta-hydroxysterol-delta(24)-reductase $(D H C R 24)$ (fold change $=0.484)$. These genes play very importance roles in maintaining the normal survival status. Homozygous HSD17B2 knockout mice would result in embryonic 
lethality (Rantakari et al., 2008). Gene knockout of the KCNJ8-encoded Kir6.1 $\mathrm{K}_{\text {ATP }}$ channel is predisposed to an early and profound survival disadvantage (Kane et al., 2006). Targeted disruption of DHCR24, an enzyme catalyzing the conversion of desmosterol to cholesterol, caused death in mice within a few hours after birth (Mirza et al., 2006). Angiotensinogengene knockout mice are not able to restore blood pressure and sodium-water depletion to normal levels, and about 60\% do not survive until weaning (Umemura et al., 1998). Tsan et al. (1998) have shown that homozygous Mn superoxide dismutase (Sod2) gene-knockout mice $\left(\right.$ Sod $\left.^{--/}\right)$die shortly after birth with extensive myocardial injury. Smad5 has been implicated as a downstream signal mediator for several bone morphogenetic proteins. Homozygous mutant embryos die between E9.5 and E11.5, and display variable phenotypes (Chang et al., 1999). The Smad 2 gene knockout mice were independently researched by three groups. Although different strategies were used, all mutant mice died during the early stage of embryonic development, indicating that Smad2-mediated TGF- $\beta$ signals are required for the early development of embryos (Nomura and Li, 1998; Waldrip et al., 1998; Weinstein et al., 1998).

The results of this study are completely from the whole genome microarray data comparing Ayu17-449 knockout and wild-type mice. They reveal that Ayu17-449 regulates the expression of several important genes involved in complement and coagulation cascade, complement activity, metabolism and cell differentiation, proliferation, and apoptosis. These data only provide a road map for future studies, a great deal of research is needed to understand the true biological activities of Ayu17-449 gene, by gene addition, protein-protein interaction or other methods.

\section{ACKNOWLEDGMENTS}

Research supported by the Nature Science Foundation of China (\#30671080).

\section{REFERENCES}

Aasrum M and Prydz H (2002). Gene targeting of tissue factor, factor X, and factor VII in mice: their involvement in embryonic development. Biochemistry (Mosc.) 67: 25-32.

Agellon LB, Drozdowski L, Li L, Iordache C, et al. (2007). Loss of intestinal fatty acid binding protein increases the susceptibility of male mice to high fat diet-induced fatty liver. Biochim. Biophys. Acta 1771: 1283-1288.

Aoki N (2005). The past, present and future of plasmin inhibitor. Thromb. Res. 116: 455-464.

Baes M, Huyghe S, Carmeliet P, Declercq PE, et al. (2000). Inactivation of the peroxisomal multifunctional protein-2 in mice impedes the degradation of not only 2-methyl-branched fatty acids and bile acid intermediates but also of very long chain fatty acids. J. Biol. Chem. 275: 16329-16336.

Blajchman MA, Austin RC, Fernandez-Rachubinski F and Sheffield WP (1992). Molecular basis of inherited human antithrombin deficiency. Blood 80: 2159-2171.

Bless NM, Huber-Lang M, Guo RF, Warner RL, et al. (2000). Role of CC chemokines (macrophage inflammatory protein-1 beta, monocyte chemoattractant protein-1, RANTES) in acute lung injury in rats. J. Immunol. 164: 2650-2659.

Callow MJ, Dudoit S, Gong EL, Speed TP, et al. (2000). Microarray expression profiling identifies genes with altered expression in HDL-deficient mice. Genome Res. 10: 2022-2029.

Chang H, Huylebroeck D, Verschueren K, Guo Q, et al. (1999). Smad5 knockout mice die at mid-gestation due to multiple embryonic and extraembryonic defects. Development 126: 1631-1642.

Choi Y, Qin Y, Berger MF, Ballow DJ, et al. (2007). Microarray analyses of newborn mouse ovaries lacking Nobox. Biol. Reprod. 77: 312-319.

Dewerchin M, Liang Z, Moons L, Carmeliet P, et al. (2000). Blood coagulation factor X deficiency causes partial embryonic lethality and fatal neonatal bleeding in mice. Thromb. Haemost. 83: 185-190.

Doolittle RF (2003). X-ray crystallographic studies on fibrinogen and fibrin. J. Thromb. Haemost. 1: 1559-1565. 
Ge H, Yang G, Yu X, Pourbahrami T, et al. (2004). Oligomerization state-dependent hyperlipidemic effect of angiopoietinlike protein 4. J. Lipid Res. 45: 2071-2079.

Gohda T, Makita Y, Shike T, Tanimoto M, et al. (2003). Identification of epistatic interaction involved in obesity using the KK/ Ta mouse as a Type 2 diabetes model: is Zn-alpha2 glycoprotein-1 a candidate gene for obesity? Diabetes 52: 2175-2181.

Ishiguro K, Kojima T, Kadomatsu K, Nakayama Y, et al. (2000). Complete antithrombin deficiency in mice results in embryonic lethality. J. Clin. Invest 106: 873-878.

Ito S, D'Alessio AC, Taranova OV, Hong K, et al. (2010). Role of Tet proteins in $5 \mathrm{mC}$ to $5 \mathrm{hmC}$ conversion, ES-cell selfrenewal and inner cell mass specification. Nature 466: 1129-1133.

Kane GC, Lam CF, O'Cochlain F, Hodgson DM, et al. (2006). Gene knockout of the KCNJ8-encoded Kir6.1 K(ATP) channel imparts fatal susceptibility to endotoxemia. FASEB J. 20: 2271-2280.

Khuu CH, Barrozo RM, Hai T and Weinstein SL (2007). Activating transcription factor 3 (ATF3) represses the expression of CCL4 in murine macrophages. Mol. Immunol. 44: 1598-1605.

Kosmider O, Gelsi-Boyer V, Ciudad M, Racoeur C, et al. (2009). TET2 gene mutation is a frequent and adverse event in chronic myelomonocytic leukemia. Haematologica 94: 1676-1681.

Langemeijer SM, Kuiper RP, Berends M, Knops R, et al. (2009). Acquired mutations in TET2 are common in myelodysplastic syndromes. Nat. Genet. 41: 838-842.

Livak KJ and Schmittgen TD. (2001). Analysis of relative gene expression data using real-time quantitative PCR and the $2^{-\Delta \Delta C \mathrm{~T}}$ method. Methods 25: 402-408.

Martin GG, Atshaves BP, McIntosh AL, Mackie JT, et al. (2008). Liver fatty acid-binding protein gene-ablated female mice exhibit increased age-dependent obesity. J. Nutr. 138: 1859-1865.

Mathews ST, Singh GP, Ranalletta M, Cintron VJ, et al. (2002). Improved insulin sensitivity and resistance to weight gain in mice null for the Ahsg gene. Diabetes 51: 2450-2458.

Mathews ST, Rakhade S, Zhou X, Parker GC, et al. (2006). Fetuin-null mice are protected against obesity and insulin resistance associated with aging. Biochem. Biophys. Res. Commun. 350: 437-443.

McArthur MJ, Atshaves BP, Frolov A, Foxworth WD, et al. (1999). Cellular uptake and intracellular trafficking of long chain fatty acids. J. Lipid Res. 40: 1371-1383.

Mead JR and Ramji DP (2002). The pivotal role of lipoprotein lipase in atherosclerosis. Cardiovasc. Res. 55: 261-269.

Mirza R, Hayasaka S, Takagishi Y, Kambe F, et al. (2006). DHCR24 gene knockout mice demonstrate lethal dermopathy with differentiation and maturation defects in the epidermis. J. Invest. Dermatol. 126: 638-647.

Monti J, Gross V, Luft FC, Franca MA, et al. (2001). Expression analysis using oligonucleotide microarrays in mice lacking bradykinin type 2 receptors. Hypertension 38: E1-E3.

Nibourel O, Kosmider O, Cheok M, Boissel N, et al. (2010). Incidence and prognostic value of TET2 alterations in de novo acute myeloid leukemia achieving complete remission. Blood 116: 1132-1135.

Nomura M and Li E (1998). Smad2 role in mesoderm formation, left-right patterning and craniofacial development. Nature 393: 786-790.

Rantakari P, Strauss L, Kiviranta R, Lagerbohm H, et al. (2008). Placenta defects and embryonic lethality resulting from disruption of mouse hydroxysteroid (17-beta) dehydrogenase 2 gene. Mol. Endocrinol. 22: 665-675.

Ruggeri ZM (1997). Mechanisms initiating platelet thrombus formation. Thromb. Haemost. 78: 611-616.

Shimamura M, Matsuda M, Yasumo H, Okazaki M, et al. (2007). Angiopoietin-like protein3 regulates plasma HDL cholesterol through suppression of endothelial lipase. Arterioscler. Thromb. Vasc. Biol. 27: 366-372.

Tang H, Araki K and Yamamura K (2006). Cloning and expression analysis of a murine novel gene, Ayu17-449. Yi. Chuan Xue Bao. 33: 413-419.

Tang H, Araki K, Li Z and Yamamura K (2008). Characterization of Ayu17-449 gene expression and resultant kidney pathology in a knockout mouse model. Transgenic Res. 17: 599-608.

Terkelsen OB, Jahnen-Dechent W, Nielsen H, Moos T, et al. (1998). Rat fetuin: distribution of protein and mRNA in embryonic and neonatal rat tissues. Anat. Embryol. (Berl) 197: 125-133.

Tsan MF, White JE, Caska B, Epstein CJ, et al. (1998). Susceptibility of heterozygous MnSOD gene-knockout mice to oxygen toxicity. Am. J. Respir. Cell Mol. Biol. 19: 114-120.

Umemura S, Kihara M, Sumida Y, Yabana M, et al. (1998). Endocrinological abnormalities in angiotensinogen-gene knockout mice: studies of hormonal responses to dietary salt loading. J. Hypertens. 16: 285-289.

Waldrip WR, Bikoff EK, Hoodless PA, Wrana JL, et al. (1998). Smad2 signaling in extraembryonic tissues determines anterior-posterior polarity of the early mouse embryo. Cell 92: 797-808.

Weinstein M, Yang X, Li C, Xu X, et al. (1998). Failure of egg cylinder elongation and mesoderm induction in mouse embryos lacking the tumor suppressor smad2. Proc. Natl. Acad. Sci. U. S. A. 95: 9378-9383.

Westenfeld R, Schafer C, Smeets R, Brandenburg VM, et al. (2007). Fetuin-A (AHSG) prevents extraosseous calcification induced by uraemia and phosphate challenge in mice. Nephrol. Dial. Transplant. 22: 1537-1546.

Genetics and Molecular Research 10 (3): 1533-1544 (2011)

(CFUNPEC-RP www.funpecrp.com.br 